\title{
Personal Branding Cino Fajrin through Instagram
}

\section{Personal Branding Cino Fajrin melalui Instagram}

\author{
Ayang Fitrianti $^{1}$, Kharisma Ayu Febriana ${ }^{1}$, Firdaus Azwar Ersyad ${ }^{1}$ \\ ${ }^{1}$ Department of Communication, Faculty of Information Technology and \\ Communication, Universitas Semarang, Jl. Soekarno Hatta Tlogosari Semarang, Central \\ Java 59160, Indonesia \\ *Corresponding author, e-mail: ayangfitrianti@usm.ac.id
}

\begin{abstract}
Instagram is one of the social media that can help an account owner build personal branding, including in the context of this research, namely Cino Fajrin as one of the local celebgram with a very strong Semarangan character, and become one that stands out among other celebgrams in this city. The owner of the @ cinofajrin account itself is a celebgram with 115.000 followers. The method used in this research is a case study. For the results of the study found that the formation of personal branding on Instagram as a form of specialization, leadership, personality, distinguishing, becoming visible, unity, determination, and good name. Cino Fajrin looks consistent in building personal branding on his Instagram account, allowing him to increase his 'personal' value and selling power. His success in managing branding on his Instagram account, has also led him to the opportunity to work with various event organizers, brands and companies.
\end{abstract}

Keywords: Instagram, Cino Fajrin, Personal Branding, Celebgram Characters.

\begin{abstract}
Abstrak
Instagram merupakan salah satu media sosial yang dapat membantu pemilik akun membangun personal branding, termasuk dalam konteks penelitian ini, yakni Cino Fajrin sebagai salah satu selebgram lokal dengan karakter Semarangan yang sangat kuat, dan menjadi salah satu yang menonjol di antara para selebgram lainnya di kota ini.Pemilik akun @ cinofajrin ini sendiri merupakan selebgram dengan jumlah followers mencapai 115.000. Metode yang digunakan dalam penelitian ini yakni studi kasus. Untuk hasil penelitian menemukan bahwa pembentukan personal branding di Instagram sebagai bentuk dari spesialisasi, kepemimpinan, kepribadian, pembeda, menjadi terlihat, kesatuan, keteguhan, dan nama baik. Cino Fajrin terlihat konsisten dalam membangun personal branding pada akun instagramnya, membuatnya dapat meningkatkan nilai dan daya jual 'pribadinya.' Keberhasilannya memanajemen branding di akun instagramnya, juga telah mengantarkannya pada kesempatan bekerjasama dengan berbagai panitia kegiatan, merek maupun perusahaan.
\end{abstract}

Kata Kunci: Instagram, Cino Fajrin, Personal Branding, Karakter Selebgram.

\section{Introduction}

The internet makes important contributions to society through the benefits it offers, such as time, space, and even financial efficiency in the communication process (Effendy, 2011). On the other hand, Nurjaman and Umam (Nurjaman \& Umam, 2012), stated the definition of communication as a word that includes all interactions with other people, whether ordinary conversation, cajoling, rewarding, or negotiating, where current communication can be practiced in many ways. One of the most often done is to use social media that is supported by the internet network.

The increase in internet usage in Indonesia itself is dominated by people accessing social media. As we know, social media is the latest development of new internet-based

Article History: Received October 04, 2019; Revised January 05, 2020; Accepted January 20, 2020; Published January 31, 2020 
web technologies, which certainly makes it easier for everyone to be able to communicate, participate, share and form online networks, so they can disseminate their own content. Posts on blogs, tweets or Youtube videos can be reproduced and can be seen directly by millions of people for free (Zarella, 2010).

Social media comes in various forms, including Twitter, Facebook, blogs. The term media can be explained as a means of sending messages from the communicator to the communicant. Social meaning refers to the work of cooperatives, which are presented by the characteristics of cooperation and individuals complementing each other by means of having a quality society (Nasrullah, 2016). Therefore, we can say that through social media, people can connect with everyone on the same social media to share information and communicate. Social media is more interactive than other traditional media, such as radio or television.

The characteristics of social media, according to Nasrullah (Nasrullah, 2016), firstly is social media as a social network, where information turns into an important identity of social media. Through social media, we can create, access, and add information. After that, the user can interact, both between users and media content producers. The point second is a social simulation which means that social media users are considered as digital citizens, and the last has user-generated content, where the content is fully owned and based on user contributions or account owners. What is communicated can provide the 'power of effect' itself because of access to technology and also 'interaction media' that can be communicated by text, images, photos, audio and video (Sulianta, 2010).

One of the most popular social media is Instagram. The name 'insta' part of the word Instagram comes from the word 'instant', like a polaroid camera in its golden era better known as 'instant photos.' Instagram can display photos instantly, like Polaroid in its view. Meanwhile, the word 'gram' comes from the word 'telegram', which is how telegrams send information to other people quickly. Similar to Instagram that can upload photos using the internet, so that information can be received quickly. Therefore, Instagram is one of the new media that brings many changes to people's lives. The online shop is developing well thanks to Instagram. Instagram indirectly becomes an effective advertising medium for advertising new products.

Based on previous research, Instagram is one of the well-developed social media. That's because Instagram offers more specific features like a high-tech application that shares photos and videos quickly. Instagram has created a new phenomenon in society at large that marks the uniqueness, expertise, and characteristics that are different in each Instagram account.

The use of internet-based social media which is most popular among teenagers is now also Instagram. In line with statistics obtained from We Are Social's, in early 2016, the percentage of Instagram users in Indonesia reached 10\% of the total population. Many businesses have grown through the Instagram app (Kemp, 2016). Instagram is used as a medium in promoting and selling products. Now, it's not just companies that have Instagram accounts that can do marketing (Kottler, 2012).

Besides, as a social media sharing photo, Instagram has 45 million active users every month in 2017 in the first quarter in Indonesia. Instagram users in Indonesia are the largest community in the Asia Pacific. The number of Instagram users has more than doubled from 22 million at the start of last year. Indonesia has become one of the largest Instagram markets in the world which now has 700 million active users globally, based on internal data as of April 2017. As such, it places Indonesia in the top 5 countries that 
most often use Instagram as a business account. At present, there are 8 million Instagram accounts that are used as business profiles worldwide (Tjiptono, 2011).

The presence of Instagram has another function, not only building a brand, but Instagram also builds personal branding where everyone is unique from birth. Its uniqueness can be in the form of names, faces, characteristics, talents, and many others that can distinguish one person from another person. Personal branding is the process of embracing one's unique skills, personality, and characteristics to make the best of them as an identity that has more power than others. Indirectly, personal branding is built by an individual from his job and profession.

Cino Fajrin is one of the Instagram influencers in Semarang who has strong local characteristics in the region, that's why Instagram influencers make an account as one of the most prominent accounts among Semarang Instagram influencers. The owner of @ cinofajrin is an Instagram influencer who has more than 115.000 followers. In this study, Cino Fajrin was the source chosen by the researchers, because Cino Fajrin was one of the Instagram influencers who were consistent with the concept he made on Instagram. It can be seen on his Instagram that Cino Fajrin uploaded a photo theme 'dubbing video' in Semarang and several photos that are relevant to his work as an artist, which is an artist of her account. When other Instagram influencers changed their Instagram account, Cino Fajrin is consistent with the themes he has had since he focused on becoming an Instagram influencer, an Instagram influencer who distinguishes the characteristics of humor that he combines with Central Javanese culture into his Instagram.

Meanwhile, for previous studies of similar themes, the first was taken from the [Jurnal The Messenger] (Volume 10, No. 2, 2018) with the title 'The Meaning Construction of Public Relations Marketing of Islamic Private Higher Education PR' by Tresna Wiwitan and Neni Yulianita. For the research problems examined in the study, namely the construction dimensions of the meaning of Marketing Public Relations in Unisba and Unissula, while the problems studied in the Cino Fajrin study program are one of the Semarang local celebrities with strong Semarangan characters using Instagram media. The research methods used are qualitative research using a case study approach. The theory used to study and analyze the results of research is the theory of social construction Berger and Luckman (Wiwitan \& Yulianita, 2018) while researchers use the study of the personal branding, brands, Instagram, endorsers, and social media.

Second, another study with the title 'Group Dynamics in the Cyberspace (Case Study on 'Komunitas Blogger Jogja' and 'Loenpia Dot Net' from the [Jurnal The Messenger] (Volume 11, No. 1, 2019) by Ayu Amalia, and Filosa Gita Sukmono from Universitas Muhamadiyah Yogyakarta (UMY). The context of this research is derived from the study of communication, emphasizing the perspective of 'cultural shift' as a result of the phenomenon of 'cyberspace' as a result of current computing technology, and changes in patterns of information and communication transmission. This research together uses social media, where the community starts to make Instagram as a form of self-existence and also emphasizes the perspective of shifting from conventional culture to celebrity culture (Amalia \& Sukmono, 2019). The research method used is descriptive qualitative with researchers. conduct in-depth interviews with members of the blogger community, such as 'Jogja Blogger Community' (bloggerjogja.org), and 'Loenpia Dot Net' (loenpia.net/blog) which is a blogger community-based in Semarang. Whereas in the research that the author did to make observations, indepth interviews with Cino Fajrin. 
Third, the research proceedings and community service, with the title 'Pengaruh Media Sosial terhadap Perilaku Remaja (The Effect of Social Media on Teen Behavior)' (Volume 3, No. 1, 2016), was examined by Wilga Secsio Ratsja Putri, Nunung Nurwati, and Meilanny Budiarti S. Research problems this is for the community, especially among adolescents, social media has become an opiate that makes users no day without opening social media. Yet in its development period, in adolescent schools trying to find their identity by hanging out with their peers. The study aims to find out what are the influences on adolescent behavior caused by social media today (Putri, Nurwati, \& Santoso, 2016). In the research that the authors wrote, they also used Instagram social media as their existence and have a big name. Previously, people did not know Cino Fajrin, but after becoming a celebrity with Instagram strength, now many Instagram users in the city of Semarang know Cino Fajrin.

In research Wilga Secsio Ratsja Putri and the team, together with Cino Fajrin's Instagram research, researchers used qualitative research methods because they wanted to explore facts, symptoms and events of social media influence. For the difference, in Instagram Cino Fajrin's research emphasizes the figure of the celebrity and its impact after using Instagram media, while in comparative research it emphasizes more on adolescent behavior in the field as it is in the context of space and time as well as the natural environment situation of adolescents. The results of comparative research are also indepth information about the influence of social media on adolescents themselves. The era of globalization is characterized by increasingly advanced technology, it cannot be denied that the presence of the internet is increasingly needed in everyday life, both in socialization activities, education, business, and so on. Yet in its development period, in adolescent schools trying to find their identity by hanging out with their peers. This study can determine the influence of social media on the influence of social media for adolescents in their later development to determine the effect on adolescent behavior caused by current social media (Ersyad, Watie, \& Setyowati, 2018).

Meanwhile, maintaining and expanding brand equity is very challenging. Brand equity management activities include how the brand strategy must reflect the company and be adjusted from time to time by considering geographical boundaries or market segments (Swasty, 2016). Besides, forming branding is almost the same as social media Facebook or Instagram, blog readers of course also be curious about the photo of the account owner. For this reason, there is also a feature by adding a profile photo (Ersyad, 2019). Based on the reasons above and also the background of the research that the author has described, this study (How Cino Fajrin built his Personal Branding through Instagram) is significant to do.

\section{Method}

This is descriptive qualitative research. A qualitative approach is a research procedure that produces descriptive data in the form of written or oral data from people and observed behavior (Bungin, 2012). The purpose of qualitative research is to understand what is hidden behind a phenomenon that is difficult to understand. The researcher uses a qualitative approach because the focus of the research under study is the experience of celebrities @Cinofajrin in managing his Instagram account, so he can build personal branding as desired.

This research uses the case study research method. In case of study research, an indepth examination of a situation or event is called a case by using systematic methods of observing, collecting data, analyzing information, and reporting results. Case studies 
aim to understand the object under study. For the scope/focus of this research is related to the strategy of managing Instagram accounts conducted by @Cinofajrim selebgram in forming personal branding the desired.

The informant of this research is a celebrity from Semarang, Cino Fajrin. The research was conducted in the city of Semarang. This research uses interview data collection methods. Interviews are conversations conducted between researchers and those studying to get information about the object under study. Researchers also use data collection techniques such as observation. Some information can be obtained from observations of space (place), actors, activities, objects, actions, events or events, time and feelings. Observation is used to present a realistic picture of a behavior or event, to answer questions, to help understand behavior, and to evaluate or measure certain aspects (Bungin, 2012). Data in the form of documents are also used in this study to describe how Instagram account management is carried out by the research object. The documents referred to here are obtained through observing the Instagram account belonging to the object of research.

This aims to facilitate researchers in understanding and interpreting the results of research. In this study, after researchers obtain information from interviews, observations and document studies, the researchers will then sort out which data can be used and which should be discarded. After that, the researcher will process the data into a narrative to make it easier to understand. If the narration has been made, then the researcher can conclude what has been studied. Research methods in communication research can be distinguished based on the approach. This approach is a fundamental philosophy of a research methodology (Kriyantono, 2016).

\section{Results and Discussion}

Observations are used to present a realistic picture of behavior or events, to answer questions, to help understand behavior, and to evaluate or measure certain aspects (Bungin, 2012). Data in the form of documents are also used in this study to illustrate how Instagram account management is carried out by research subjects. The documents referred to here were obtained by observing's Instagram account. Cino FajrinThrough this process, researchers found out how Cino Fajrin formed his personal branding by using Instagram features. The results showed that the formation of personal branding by Muhammad Yanuar Fajrin as the owner of the Cino Fajrin account was in accordance with the eight concepts of formation personal branding according to Montoya (in Haroen, 2014), among others:

First is specialization (the law of specialization). The characteristic of a good personal brand is accuracy in specialization, concentrated on certain strengths, abilities, or achievements. Correspondingly, Cino Fajrin has special characteristics in uploading funny content on his Instagram. His Instagram account uses Javanese which shows that Cino Fajrin wants to be considered a funny person and wants to show that he is from Semarang City.

One of Cino Fajrin's photo posts that uses the Javanese Language is "Beb @ pevpearce, termos mu ketinggalan. Engko 'rak 'iso godok 'Pop Mie' neng sepur (Honey@pevpearce, your thermos is left behind. You can't cook 'Pop Mie' on the train later)." Cino Fajrin post has used the feature in the form of photo uploads (images edited by Cino Fajrin with Pevita Pearce), photos by adding effects so the images can be brighter, useful for reinforcing information on the title "Beb@pevpearce, termos mu ketinggalan. 
Engko 'rak 'iso godok 'Pop Mie'neng sepur (Honey @ pevpearce, your thermos is left behind. You can't cook 'Pop Mie' on the train later)." In addition, Cino Fajrin also uses Arroba by mentioning @ pevpearce in the title of the uploaded photo. He also uses geotagging at Semarang Poncol Station and the number of likes given by followers he reaches 10.566 likes, which of course automatically places the @ cinofajrin account on browsing or popular feature.
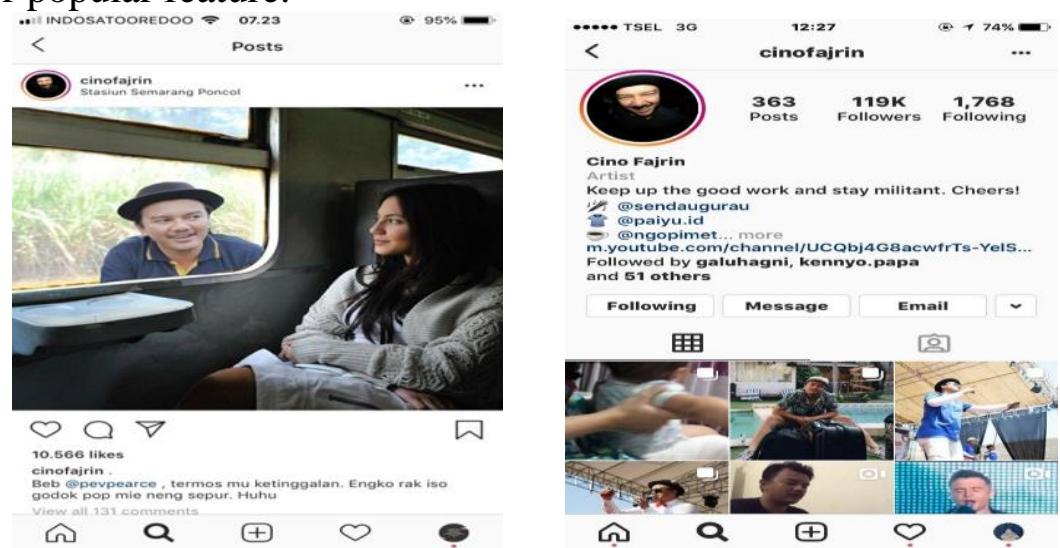

Figure 1. Photo Post of Cino Fajrin with Pevita Pearce

Second, namely the existence of leadership (the law of leadership). The personal brand is complemented by a leading figure who can make decisions in uncertain situations and can give clear instructions. A follower owned by Cino Fajrin around 115k (115.000) shows that he is an Instagram content creator who leads in Semarang City, compared to other local Instagram account owners in Semarang, like Instagram account @ sela_good (18.6K), @obinrobin (10.1K), and @ mayangcharisma (54.5K).

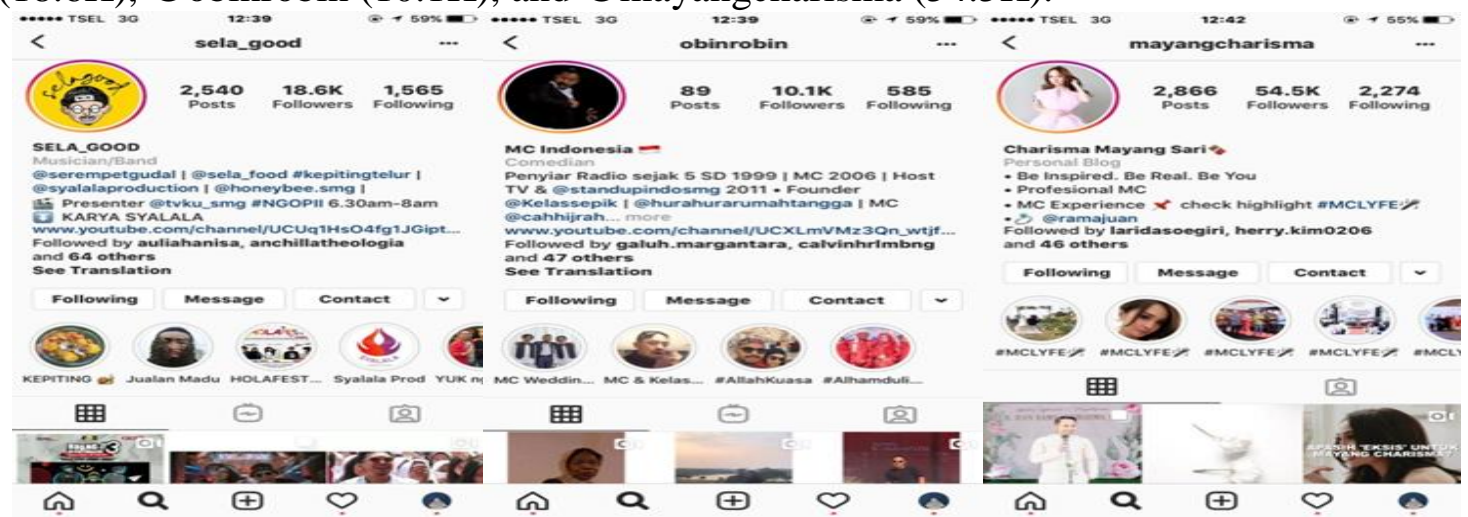

Figure 2. Instagram Accounts of Cino Fajrin's competitors

With so many followers on Instagram accounts, it is automatically makes Cino Fajrin a role model for followers. Therefore, whatever Cino Fajrin said would most likely be followed by his followers. One of them can be seen in his post where Cino Fajrin invited his followers to enjoy his music and invited them to use social media wisely. 

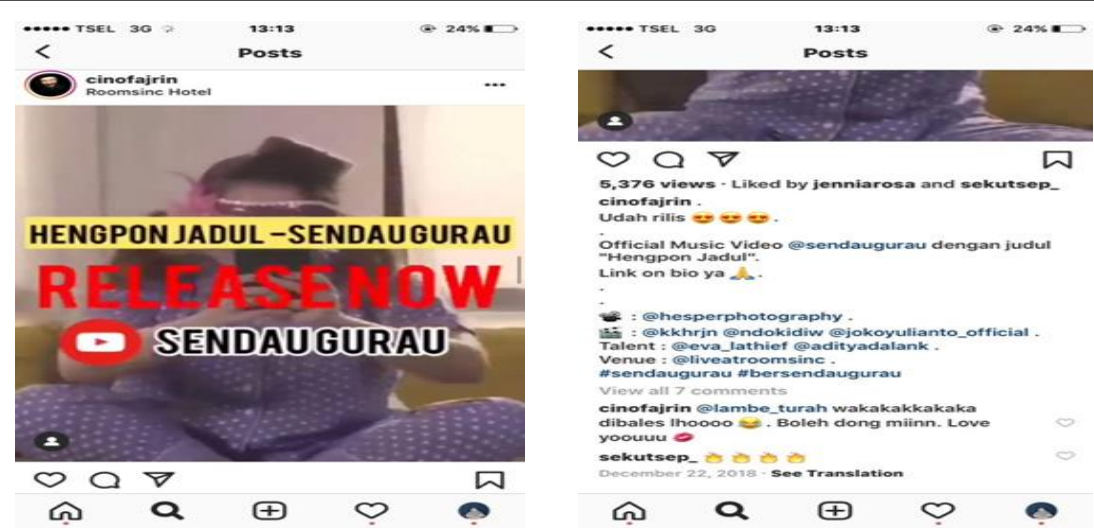

Figure 3. Cino Fajrin's Post about His Music Work

The third concept is personality (the law of personality). Great personal brands are based on humble personalities and are presented with imperfections. Cino Fajrin's personality is described as being funny, fun, and 'slengean (prank)' in his uploaded photos and also videos.

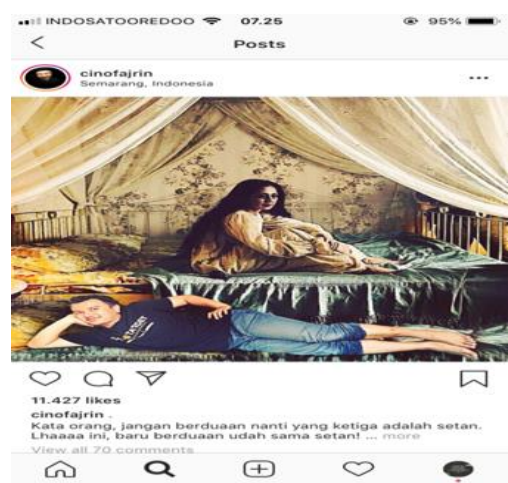

Figure 4. Post 'Slengean (Prank)' Cino Fajrin's on Instagram

The picture above shows that Cino Fajrin uploaded content in the form of photos that had gone through an editing process. His bed was next to 'Ibu (Mother)' which is an icon of the film 'Pengabdi Setan (Servant of Satan)' which was once a trend in Indonesia. When you think about it logically can't happen, this is what makes people think that Cino Fajrin has a unique personality, so that it can create content while making this post liked by 11.427 followers. Next is the fourth difference (the law of distinctiveness). Personal branding effective must be presented in a way that is different from the others.

Differentiation is needed to differentiate from one another. A part from that, a person will be widely known because he is different from the others. Cino Fajrin shows that he has a different character from his musician's soul which can be seen from the photos and videos he uploaded on Instagram that shows the appearance of his daily music career.

Next or the fifth is seen (the law of visibility). Personal branding must be seen consistently and continuously until the personal brand is widely known. Therefore, visibility is more important than ability. To be seen, a person must promote himself and use every opportunity to let himself be seen and continue to be seen, and use Instagram from the beginning, in every activity or project he does, Cino Fajrin always uploads it on his social media, such as when he was an MC, a guest speaker, or when he is featured in promotions on his social media that shows where he is.

The sixth is unity (the law of unity). The personal life behind personal branding must be in line with the moral ethics and behavior decided by it. Personal life 
must be the reflection and image desired in a personal brand. Uploading Instagram photos of Cino Fajrin fits his funny, fun characteristics, adapted to the way he does his daily activities, not just as an Instagram influencer.

Next (seventh), constancy (the law of persistence). Personal branding cannot be built instantly. Throughout the process, it is important to always pay attention to the steps and trends. Cino Fajrin consistently makes works by uploading photos and videos regularly on Instagram before and now when he already has 115 thousand followers. Besides, he updates the changing trends by connecting Instagram to other social media links, such as YouTube.

The last (eighth) is a good name (the law of goodwill). Personal branding will give good results and last longer if the person behind is considered to have a positive image. That person will be associated with values or ideas that are generally recognized as positive and useful. Cino Fajrin built his good intentions on using Instagram by not only uploading funny photos and videos but also uploading photos and content that looked eccentric but also positive. The message in his work convinced followers to use social media wisely.

The eight concepts personal branding above are in line with the results of researchers' interviews with research subjects, namely Muhammad Yanuar Fajrin. Based on the results of the interview, Muhammad Yanuar Fajrin or more familiarly called Cino Fajrin said that personal branding is the character of someone who is shown to the public, both appearance and behavior are very important to be formed, especially to determine market share in the profession. Cino Fajrin was involved in the communication process that he said including via Instagram.

The statement was supported by Nasrullah (2016), who said the term media as a means of delivering messages from the communicator to the communicant. Social meaning refers to cooperative work, that is the character of cooperation or complementarity between individuals to form a new quality of society, so that it can be interpreted that, through social media a person can connect who are members of the same social media to share information. Social media has a more interactive nature when compared to traditional forms of media such as radio and television (Morisan \& Wardhani, 2006). Furthermore, what was conveyed by CinoFajrin in an interview with researchers related to the function of personal branding, which was formed was humorous, fun and 'slengean (prank), ' to give a certain character in him which then aims to form a market in the profession in that field, namely in entertainment field.

This statement is in line with Nisrina's statement (Nisrina, 2015) that Instagram as an application is used to distribute photos and videos. Instagram itself is still part of Facebook which allows Facebook friends to follow their Instagram account. Instagram's growing popularity as an application used for sharing photos has caused many users to enter online businesses to promote their products through Instagram, in this case the promotion itself through the personal branding that he has done.

Based on interview results, the researchers also found that Cino Fajrin's beginnings were known on Instagram through the creation of funny content on social media, and that is what makes Cino Fajrin stick to the present to the researchers themselves determining the character in personal branding. In our opinion as researchers, character on personal branding is very important. This is based on Dewi Haroen's opinion (Haroen, 2014) which states that branding is an activity carried out to build the perception of others about us or about who we are. Branding is an effort to introduce a product until the product is known, 
recognized, and used by the public. Branding is done to make an image that is following what is desired by the product owner, the product referred to here is Cino Fajrin itself.

Another thing that researchers found in the interview was why Cino Fajrin chose Instagram as a medium to introduce himself to the community, in his opinion, Instagram was the easiest and most complete social media feature from the beginning until now. CinoFajrin later also said that he began to be known for being consistent with the characters fun and funny thing that has appeared since 2017, so this is comparable to the requests he gets from the audience to fill events in Semarang and other cities.

This made Cino Fajrin no longer ashamed to honestly affirm his original character who was funny and displayed in front of many people. Personal branding in Cino Fajrin 'sells' and distinguishes from others. Personal branding shapes the public perception used by Cino Fajrin in his life. Based on the results of the interview, the researchers also found that personal branding is not only needed for people who appear in public, but for anyone who needs it. So not only public figures or celebrities who need personal branding, but each individual can also do personal branding related to what is desired from the formation of the perception of others.

Personal branding according to Cino Fajrin is a public perception about aspects possessed by individuals, including CinoFajrin's personality that is highlighted on his Instagram account, which is fun and humorous characters. His ability to be a guest speaker, MC, and also a music player, where all of that leads on positive perceptions from the public which can eventually be used as a marketing tool and this happens to Muhammad Yanuar Fajrin who has an Instagram account @ cinofajrin.

One thing that is emphasized by Muhammad Yanuar Fajrin is that he must consistently maintain and improve the personal branding he gets in public perception, namely by continuing to work consistently following thecharacter personal branding that has been formed starting from 2017. Speak and McNally (McNally \& Speak, 2002) in his book 'Be Your Own Brand' also shows that with consistency, people become convinced of their potential during daily social interaction.

\section{Conclusion}

Personal branding on Muhammad Yanuar Fajrin or better known as Instagram account @ cinofajrin as a whole is following eight concepts of the formation of personal branding according to Montoya (in Haroen, 2014) namely: specialization (the law of specialization), leadership (the law of leadership), personality (the law of personality), difference (the law of distinctiveness), visible (the law of visibility), unity (the law of unity), constancy (the law of persistence) and good name (the law of goodwill).

Meanwhile, for subsequent studies, the research team suggested using the same research theme (building personal branding) but with different subjects and social media application platforms, so that it is possible to explore the results of research differently about personal branding. Further research can also be done, comparing how the communication strategies used by public figures when building personal branding from different social media application platforms.

\section{Acknowledgements}

In this study, the team of authors would like to thank the Research and Community Service Institute (LPPM) of the Universitas Semarang, and also thank the Faculty of Information Technology and Communication, Universitas Semarang, which has 
supported and facilitated all the processes of preparing research reports, and also thanks to Cino Fajrin for being willing to spend his time as a resource in this study.

\section{References}

Amalia, A., \& Sukmono, F. G. (2019). Group Dynamics in the Cyberspace (Case Study on 'Komunitas Blogger Jogja' and 'Loenpia Dot Net'). Jurnal The Messenger, 11(1), 46. https://doi.org/https://doi.org/10.26623/themessenger.v11i1.812

Bungin, B. (2012). Penelitian Kualitatif Komunikasi,Ekonomi, Kebijakan Publik, dan Ilmu Sosial Lainnya. Jaka: Kencana Prenada Media Group.

Effendy, O. (2011). Ilmu Komunikasi Teori Komunikasi. Bandung: Remaja Rosdakarya.

Ersyad, F. A. (2019). Membangun Profesional Branding Dengan Website Berbasis WordPress. Yogyakarta: Deepublish.

Ersyad, F. A., Watie, E. D. S., \& Setyowati, R. M. (2018). The Logo Analysis from Faculty of Information Technology and Communication of Universitas Semarang in order to Redesign the Logo and the Corporate Identity Design using Logotype $\begin{array}{llll}\text { Method. Jurnal The } 104 . & \end{array}$ https://doi.org/https://doi.org/10.26623/themessenger.v10i1.715

Haroen, D. (2014). Personal Branding : Kunci Kesuksesan Berkiprah di Dunia Politik. Jakarta: Gramedia.

Kemp, S. (2016). DIGITAL IN 2016. Retrieved September 17, 2019, from wearesocial.com website: https://wearesocial.com/special-reports/digital-in-2016

Kottler., P. (2012). Manajemen Pemasaran. Semarang: Erlangga.

Kriyantono, R. (2016). Teknik Praktis Riset Komunikasi. Jakarta: Kencana Prenada Media Group.

McNally, D., \& Speak, K. D. (2002). Be Your Own Brand. American Salesman, 47, 2930.

Morisan, \& Wardhani, A. C. (2006). Teori Komunikasi tentang Komunikator, Pesan, Percakapan dan Hubungan. Semarang: Ghalia Indonesia.

Nasrullah, R. (2016). Konstruksi Makna Marketing Public Relations bagi Humas Perguruan Tinggi Swasta Islam. Bandung: Simbiosa Rekatama Media.

Nisrina, M. (2015). Bisnis Online, Manfaat Media Sosial Dalam Meraup Uang. Yogyakarta: Kobis.

Nurjaman, K., \& Umam, K. (2012). Komunikasi dan Public Relations. Bandung: CV. Pustaka Setia.

Putri, W. S. R., Nurwati, R. N., \& Santoso, M. B. (2016). Pengaruh Media Sosial Terhadap Perilaku Remaja. Prosiding Penelitian Dan Pengabdian Kepada Masyarakat, 3(1). https://doi.org/https://doi.org/10.24198/jppm.v3i1.13625

Sulianta, F. (2010). Stereogram: Sihir Dunia Digital. Jakarta: Elex Media Komputindo.

Swasty, W. (2016). Branding Memahami dan merancang strategi merek. Bandung: Remaja Rosdakarya.

Tjiptono, F. (2011). Pemasaran Jasa. Malang: Bayu Media.

Wiwitan, T., \& Yulianita, N. (2018). The Meaning Construction of Public Relations Marketing of Islamic Private Higher Education PR. Jurnal The Messenger, 10(2). https://doi.org/https://doi.org/10.26623/themessenger.v10i2.870

Zarella, D. (2010). The Social Media Marketing Book. Jakarta: Serambi Ilmu Semesta. 